\title{
Effects of Methanolic and Aqueous Extract of Cucumis metuliferus Fruits on Newcastle Disease in Pullets
}

\author{
Salisu U.S. ${ }^{1 *}$, Sabo M.N. ${ }^{1}$, Garba M.G. ${ }^{1}$, Jamilu R.Y. ${ }^{1}$, Zaharadeen \\ A.S. ${ }^{2}$, Sanusi A.Z. ${ }^{1}$, and James G.U. ${ }^{3}$ \\ ${ }^{1}$ Department of Animal Science, Federal University Dutsinma, Katsina State \\ ${ }^{2}$ Department of Biochemistry, Federal University Dutsinma, Katsina State \\ ${ }^{3}$ College of Veterinary Surgeons, Ahmadu Bello University Zaria Study Center
}

\begin{abstract}
The study was conducted to determine the effect of aqueous and methanolic extracts of Cucumis metuliferus fruit on the prevention and cure of Newcastle Disease (NCD) in pullets. Ninety (90) pullets were used for the experiment. The pullets were divided into 9 groups, 4 prophylactics, 4 curative and one control group. For prophylactic groups, aqueous extract of the fruit at a concentration of $2.5 \mathrm{~g}$ and $5.0 \mathrm{~g} /$ /litre of water and methanolic extract of the fruit at 75 and 50 $\mathrm{mg} /$ litre were given to the pullets ad-libitum for two weeks and then challenged with Newcastle disease virus kudu 113 strain via intra-ocular route while for curative groups, the pullets were challenged with the virus and then treated with the aqueous and methanolic extracts of the fruits at the same concentrations. The results showed that methanolic extract of $C$. metuliferus at a concentration of $75 \mathrm{mg} / \mathrm{l}$ showed superior prophylactic ability recording lower clinical signs, mortality, postmortem lesions, higher antibody titre and higher white blood cell activity and also exhibited very good therapeutic potential. It was thus suggested that methanolic extract of $C$. metuliferus at $75 \mathrm{mg} / \mathrm{l}$ can be recommended for the control of NCD to farmers and that further studies be conducted to isolate the alkaloids of C. metuliferus responsible for these findings.
\end{abstract}

Keywords - Newcastle disease, Cucumis metuliferus, pullets, Methanolic extract, Aqueous extract.

\footnotetext{
*Corresponding author:

email: usalisu@fudutsinma.edu.ng

Tel: +2348099446287
} 


\section{INTRODUCTION}

Poultry production is the fastest-growing segment of the agricultural subsector in Nigeria due to the increased demand for animal protein in Nigeria with the ever-growing population [1]. However, one of the constraints to the development of the industry is an outbreak of diseases 1. In poultry, Newcastle Disease Virus (NDV) causes a highly infectious neurological, respiratory or enteric disease.

Newcastle disease remains a serious economic challenge to all segments of the poultry industry because of its high morbidity and mortality rates [2]. The only control method so far remains vaccination, which does not confer $100 \%$ immunity in all vaccinated birds. It has also been reported that vaccination often induces a carrier state in birds and also reduces their growth [2]. The immunity conferred on birds due to vaccination has been observed to degrade or wane over time [2], predisposing birds to become vulnerable to re-infection. There is an indication to explore alternative mechanisms to complement the protective effects of vaccinations.

Plants have been used for various purposes since prehistoric times $[3,4]$ and medicinal herbs are being increasingly studied by researchers [5]. Reports of various plants used in the treatment of diseases have been documented in various parts of the world $[6,7$, 8.] Indian Ayurveda medicine used herbs as early as 1900 BC describing 700 medicinal plants [9]. According to the World Health Organization (WHO), more than $80 \%$ of the world's populations rely on traditional medicine for their primary healthcare with the majority being plants or their active principles [10].
Cucumis metuliferus is locally called 'gautar kaji' by the Hausa tribe in Northern Nigeria [11]. The plant belongs to the family Cucurbitaceae and is a monoecious, climbing, annual herb that can be grown practically anywhere, provided the season is warm [12]. It is commonly known as African horned cucumber, melano, Jelly melon, and kiwano in the Polish language. The fruits occur in two forms: the bitter and non-bitter forms, which occur mostly in the wild state. The bitter form contains cucurbitacins (triterpenoids), which is a highly toxic compound [11]. The non-bitter form is less toxic and has also been widely cultivated [13]. The plant is endemic to the semi-arid regions of Southern and Central Africa [13]. Its fruits are ovoid berries of 8-10 $\mathrm{cm}$ long and $4-5 \mathrm{~cm}$ in diameter, reddishorange at maturity, hanging, covered with strong spiny outgrowths and the seeds are embedded in the mesocarp which is emerald green and consists of juicy, bland-tasting tissues. It is reported that the fruits and seeds of Cucumis metuliferus are eaten raw as supplements by local populations of Africa [11, 13]. Reports have also shown that the seeds can be ground into fine flour, made into an emulsion with water, and then eaten to expel parasites (helminths) from the body [14].

Local poultry farmers in the study area lay claim to the efficacy of Cucumis metuliferus fruits in the treatment of their birds for various diseases including Newcastle disease by immersing the whole fruits in the drinking water of birds (Personal communication, 2017). The present research is designed, therefore, to evaluate the effects of methanolic and aqueous extract of Cucumis metuliferus fruits on Newcastle Disease infection in Pullets. 


\section{MATERIALS AND METHODS}

\section{Study Area}

The study was conducted at the Poultry Unit of the Department of Animal Science Farm, Federal University Dutsinma, Katsina State, Nigeria. Dutsinma lies within the coordinates of latitude $12.45 \mathrm{~N}$ and longitude $7.49 \mathrm{E}$ and also at the altitude of $605 \mathrm{~m}$ above the sea level15.

\section{Study Design}

The research was carried out using a Completely Randomized Design with 9 treatments, each treatment/group was made up of 5 birds. Day-old pullets were sourced from a reputable hatchery and brooded under strict biosecurity measures to prevent the entry of pathogens. The birds were vaccinated against Infectious bursal disease on day seven of the arrival but not against Newcastle disease. They were fed with chick mash. Experimental groups consisted of Curative, Prophylactic and Control groups. Aqueous solutions of Cucumis metuliferus was made at $2.5 \mathrm{~g} / 1$ and $5 \mathrm{~g} / 1$.

\section{Collection, Identification and Extraction of the Plant Sample}

Fresh fruits of $C$. metuliferus were collected from Dutsin-ma in the month of May 2018. The plant sample was authenticated by a taxonomist at the Herbarium of the Department of Biological Sciences, Ahmadu Bello University, Zaria and a voucher number (No: 1936) was assigned. The fruits were shade dried. It was reduced to coarse particles using mortar and pestle before being pulverized into fine particles using a laboratory hammer mill. Exactly $1,000 \mathrm{~g}$ of the powder was exhaustively extracted in methanol using soxhlet extraction. The extract was filtered using Whatman size 1 filter paper and the filtrate was concentrated in vacuo at $40^{\circ} \mathrm{C}$. The extract was stored in a refrigerator at $4^{0} \mathrm{C}$ for further use in the studies.

\section{Experimental Design}

The curative groups were T1 and T2 (administered $2.5 \mathrm{~g} / 1$ and $5 \mathrm{~g} / 1$ aqueous extracts respectively) and $\mathrm{T} 3$ and $\mathrm{T} 4$ (administered 50 $\mathrm{g} / 1$ and $75 \mathrm{~g} / 1$ methanolic extracts respectively). These groups were initially challenged with the Newcastle disease virus Kudu 113 strain at a dose of 107.8/ 0.1 ml/bird at 8 weeks and treated as indicated depending on the group's ad libitum in drinking water as soon as clinical signs were observed. The prophylactic groups were $\mathrm{T} 5$ and $\mathrm{T} 6$ (administered $2.5 \mathrm{~g} / 1$ and $5 \mathrm{~g} / 1$ aqueous extracts respectively) and $\mathrm{T} 7$ and $\mathrm{T} 8$ (administered 50 $\mathrm{g} / 1$ and $75 \mathrm{~g} / 1$ methanolic extracts respectively). These groups were treated with indicated treatments ad libitum in water for 2 weeks and then subsequently challenged with Newcastle disease virus Kudu 113 strain at a dose of $107.8 / 0.1 \mathrm{ml} /$ bird to observe if the treatments would prevent or reduce the intensity of infection. The control group was challenged with the Newcastle disease virus Kudu 113 strain at the same dose but was not treated with any extracts at 8 weeks of age.

\section{Study Parameters}

The clinical signs, mortality and post mortem lesions were observed and recorded daily.

\section{Laboratory Analysis}

Blood was collected via the wing vein of birds at the second and fourth weeks of the experiment. Whole blood was collected for 
haemogram/blood picture and the serum for Haemagglutination inhibition test.

\section{Data Analysis}

Data obtained from the experiment were subjected to analysis using one-way analysis of variance (ANOVA) and Duncan Multiple Range posthoc test. Values of $\mathrm{P}<0.05$ were considered significant. The results were presented in texts, tables and as Mean \pm SEM (standard error of the mean). SPSS version 25.0 was employed for the data analysis.

\section{RESULTS}

\section{Clinical Signs}

The clinical signs of ND observed included: gasping, sneezing, greenish diarrhoea, anorexia, torticollis, depression, swollen head, incoordination and emaciation. For both curative and prophylactic treatments the groups administered with $75 \mathrm{~g} / 1$ of methanolic extract (groups T4 and T8) recorded the least clinical signs. Likewise, the groups treated with $2.5 \mathrm{~g} / 1$ of aqueous extract (groups T1 and T5) showed the most clinical signs (Tables 1 and 2).

Table 1: Clinical Signs for Curative Treatments of birds with Cucumis metuliferus extracts

\begin{tabular}{lcccccccccc}
\hline & \multicolumn{3}{c}{ Greenish } & & & & & Swollen & Weight & Incoordination/ \\
Treatments & Sneezing & Diarrhea & Torticollis & Anorexia & Gasping & Depression & Head & Loss & Staggering \\
\hline T1 & + & + & + & + & + & - & - & + & + \\
T2 & + & + & + & + & + & - & - & + & - \\
T3 & + & + & - & + & + & + & - & + & - \\
T4 & - & + & - & + & - & + & - & + & - \\
Control & + & + & + & + & + & + & + & + & +
\end{tabular}

Key $-\mathrm{T} 1=2.5 \mathrm{~g} / \mathrm{l}$ aqueous extract; $\mathrm{T} 2=5 \mathrm{~g} / \mathrm{l}$ aqueous extract; $\mathrm{T} 3=50 \mathrm{~g} / \mathrm{l}$ methanolic extract; T4=75 g/l methanolic extract; + = present; - = absent; $n=5$

Table 2: $\quad$ Clinical Signs for Prophylactic Treatments of birds with Cucumis metuliferus

extracts

\begin{tabular}{|c|c|c|c|c|c|c|c|c|c|}
\hline & & Greenish & & & & & Swollen & Weight & Incoordination/ \\
\hline Treatments & Sneezing & Diarrhea & Torticollis & Anorexia & Gasping & Depression & Head & Loss & Staggering \\
\hline $\mathrm{T} 5$ & + & + & + & + & + & + & + & + & + \\
\hline T6 & - & + & + & + & + & + & - & + & - \\
\hline $\mathrm{T} 7$ & - & + & - & + & - & - & - & + & - \\
\hline $\mathrm{T} 8$ & - & + & - & - & - & - & - & + & - \\
\hline Control & + & + & + & + & + & + & + & + & + \\
\hline
\end{tabular}

Key $-\mathrm{T} 5=2.5 \mathrm{~g} / \mathrm{l}$ aqueous extract; $\mathrm{T} 6=5 \mathrm{~g} / \mathrm{l}$ aqueous extract; $\mathrm{T} 7=50 \mathrm{~g} / \mathrm{l}$ methanolic extract; $\mathrm{T} 8=75 \mathrm{~g} / \mathrm{l}$ methanolic extract; $+=$ present; $-=$ absent; $\mathbf{n}=5$ 


\section{Mortality Rates}

Treatment 8 , administered $75 \mathrm{~g} / 1$ of methanolic extract amongst the prophylactic groups, was the only group that did not record any mortality. For the curative treatments, T4 (treated with 75 $\mathrm{g} / \mathrm{l}$ methanolic extracts) recorded the lowest mortality rate of 1 bird. The control group recorded the highest mortality rate of 10 followed by $\mathrm{T} 5$ which was treated with $2.5 \mathrm{~g} / 1$ of aqueous extract among the prophylactic treatments with 3 mortalities (Table 3 ).

Table 3: Mortality Rates of birds treated with Cucumis metuliferus extracts

\begin{tabular}{lc}
\hline Treatments & Mortalities \\
\hline T1 & 2 \\
T2 & 2 \\
T3 & 2 \\
T4 & 1 \\
T5 & 3 \\
T6 & 2 \\
T7 & 1 \\
T8 & 0 \\
Control & 10 \\
\hline
\end{tabular}

Key $-\mathrm{T} 1=2.5 \mathrm{~g} / \mathrm{l}$ aqueous extract; $\mathrm{T} 2=5 \mathrm{~g} / \mathrm{l}$ aqueous extract; $\mathrm{T} 3=50 \mathrm{~g} / \mathrm{l}$ methanolic extract; T4=75 g/l methanolic extract (Curative treatments), T5=2 .5 g/l aqueous extract; T6= $5 \mathrm{~g} / \mathrm{l}$ aqueous extract; $T 7=50 \mathrm{~g} / \mathrm{l}$ methanolic extract; $\mathrm{T8}=75 \mathrm{~g} / \mathrm{l}$ methanolic extract (Prophylactic treatments); $\mathbf{n}=\mathbf{5}$

\section{Post Mortem Lesions}

The post mortem lesions seen during the post mortem examinations included haemorrhage in the intestine, trachea and proventriculus, bile enlargement, cloudy air sack, haemorrhage on glandular surface of the proventriculus and necrotic areas in caecal tonsils (Table 4 and 5). 
Table 4: Post Mortem Lesions for Curative Treatments of birds treated with Cucumis metuliferus extracts

\begin{tabular}{llllllll}
\hline Treatments & HII & HIT & HOP & BE & ASC & HGSP & NCT \\
\hline T1 & + & + & + & + & + & + & - \\
T2 & + & + & + & + & + & + & + \\
T3 & + & + & + & + & + & + & + \\
T4 & + & - & + & - & - & + & + \\
Control & + & + & + & + & + & + & + \\
\hline
\end{tabular}

Key: HII - Haemorrhage in the intestine, HIT - Haemorrhage in the trachea, HOP - Heamorrhage on Proventriculus, BE- Bile duct enlargement, ASC-Cloudy air sac, HGSP-Haemorrhage on the glandular surface of the proventriculus, NCT - Necrotic areas on cecal tonsils

Table 5: Post mortem lesions for Prophylactic Treatments of birds treated with Cucumis metuliferus extracts

\begin{tabular}{llllllll}
\hline Treatments & HII & HIT & HOP & BE & ASC & HGSP & NCT \\
\hline T5 & + & + & + & - & + & + & + \\
T6 & - & + & + & - & + & + & + \\
T7 & - & - & - & - & - & + & + \\
T8 & + & - & - & - & - & - & - \\
Control & + & + & + & + & + & + & + \\
\hline
\end{tabular}

Key: HII - Haemorrhage in the intestine, HIT - Haemorrhage in the trachea, HOP -

Heamorrhage on Proventriculus, BE - Bile duct enlargement, ASC - Cloudy air sac, HGSP - Haemorrhage on glandular surface of the proventriculus, NCT - Necrotic areas on cecal tonsils

\section{Blood Picture/Haematology}

Groups T4 and T8 treated with $75 \mathrm{~g} / 1$ of methanolic extract for curative and prophylactic treatments respectively recorded the highest $\mathrm{PCV}$, total white blood cell count, as well as a total red blood cell counts for prophylactic and curative treatments respectively (Tables 6 and 7). 
Table 6: Blood Picture/Haematology (Curative Treatments)

\begin{tabular}{lllllll}
\hline Parameters & T1 & T2 & T3 & T4 & Control & SEM \\
\hline PCV & $31.00^{\mathrm{a}}$ & $24.33^{\mathrm{b}}$ & $25.33^{\mathrm{b}}$ & $36.67^{\mathrm{a}}$ & $16.00^{\mathrm{c}}$ & 2.62926 \\
HGB (g/d) & $10.20^{\mathrm{a}}$ & $8.07^{\mathrm{a}}$ & $8.43^{\mathrm{a}}$ & $5.37^{\mathrm{b}}$ & $5.53^{\mathrm{b}}$ & 0.81666 \\
TP & $4.73^{\mathrm{a}}$ & $3.53^{\mathrm{b}}$ & $4.87^{\mathrm{a}}$ & $5.27^{\mathrm{a}}$ & $3.87^{\mathrm{b}}$ & 0.15333 \\
TWBC x 10 $/ \mathbf{l}$ & $14.27^{\mathrm{a}}$ & $14.33^{\mathrm{a}}$ & $11.67^{\mathrm{b}}$ & $16.00^{\mathrm{a}}$ & $11.13^{\mathrm{b}}$ & 0.85076 \\
TRBC x 1012/l & $5.23^{\mathrm{a}}$ & $4.23^{\mathrm{a}}$ & $4.33^{\mathrm{a}}$ & $5.73^{\mathrm{a}}$ & $3.27^{\mathrm{b}}$ & 0.37389 \\
HETERO (\%) & $13^{\mathrm{a}}$ & $9^{\mathrm{b}}$ & $8^{\mathrm{b}}$ & $9^{\mathrm{a}}$ & $5^{\mathrm{c}}$ & 1.03494 \\
LYMPHO (\%) & $82^{\mathrm{a}}$ & $89^{\mathrm{a}}$ & $90^{\mathrm{a}}$ & $86^{\mathrm{a}}$ & $95^{\mathrm{a}}$ & 1.47745 \\
MONO (\%) & 0 & 2 & 1 & 0 & 0 & 0.39841 \\
EOSINO (\%) & 0 & 0 & 0 & 4 & 0 & 0.23231 \\
BASO (\%) & 0 & 0 & 0 & 0 & 0 & 0.00000 \\
BAND (\%) & 3 & 0 & 1 & 1 & 0 & 0.40237 \\
\hline
\end{tabular}

Means with the same letter are not significantly $(\mathrm{P}>0.05)$ different.

Table 7: Blood Picture/Haematology (Prophylactic Treatments)

\begin{tabular}{lllllll}
\hline Parameters & T5 & T6 & T7 & T8 & Control & SEM \\
\hline PCV & $24.33^{\mathrm{a}}$ & $25.33^{\mathrm{a}}$ & $37.00^{\mathrm{a}}$ & $44.00^{\mathrm{b}}$ & $16.00^{\mathrm{c}}$ & 1.11469 \\
HGB (g/dl) & $7.97^{\mathrm{a}}$ & $8.40^{\mathrm{a}}$ & $13.67^{\mathrm{b}}$ & $12.53^{\mathrm{b}}$ & $5.53^{\mathrm{a}}$ & 0.35017 \\
TP & $6.53^{\mathrm{a}}$ & $4.80^{\mathrm{b}}$ & $4.33^{\mathrm{b}}$ & $6.67^{\mathrm{a}}$ & $3.87^{\mathrm{b}}$ & 0.32403 \\
TWBC x 10$/ \mathbf{l}$ & $14.40^{\mathrm{a}}$ & $9.87^{\mathrm{b}}$ & $11.53^{\mathrm{a}}$ & $16.33^{\mathrm{c}}$ & $10.13^{\mathrm{b}}$ & 1.02003 \\
TRBC x 1012/l & $3.97^{\mathrm{a}}$ & $4.07^{\mathrm{a}}$ & $7.37^{\mathrm{b}}$ & $7.87^{\mathrm{b}}$ & $3.27^{\mathrm{a}}$ & 0.12794 \\
HETERO (\%) & $14^{\mathrm{a}}$ & $11^{\mathrm{b}}$ & $9^{\mathrm{b}}$ & $11^{\mathrm{b}}$ & $5^{\mathrm{c}}$ & 1.02291 \\
LYMPHO (\%) & $84^{\mathrm{a}}$ & $85^{\mathrm{a}}$ & $89^{\mathrm{a}}$ & $85^{\mathrm{a}}$ & $95^{\mathrm{a}}$ & 1.37737 \\
MONO (\%) & 2 & 3 & 0 & 3 & 0 & 0.47676 \\
EOSINO (\%) & 0 & 0 & 2 & 0 & 0 & 0.23503 \\
BASO (\%) & 0 & 0 & 0 & 0 & 0 & 0.00000 \\
BAND (\%) & 0 & 1 & 0 & 1 & 0 & 0.16330
\end{tabular}

Means with the same letter are not significantly $(\mathrm{P}>0.05)$ different.

\section{Haemagglutination Inhibition}

The $75 \mathrm{mg} / \mathrm{l}$ groups for both curative and prophylactic treatments (Groups T4 and T8) recorded the highest antibody titres of 1 in 128 and 1 in 256 respectively (Tables 8 and 9). 
Table 8: Haemagglutination Inhibition (Curative Treatments)

\begin{tabular}{lllllllllllll}
\hline Treatment & $1 / 1$ & $1 / 2$ & $1 / 2$ & $1 / 8$ & $1 / 16$ & $1 / 32$ & $1 / 64$ & $1 / 128$ & $1 / 256$ & $1 / 512$ & $1 / 1024$ & $1 / 2048$ \\
\hline T1 & + & + & + & + & + & - & - & - & - & - & - & - \\
T2 & + & + & + & + & - & - & - & - & - & - & - & - \\
T3 & + & + & + & + & + & + & - & - & - & - & - & - \\
T4 & + & + & + & + & + & + & + & + & - & - & - & - \\
Control & + & + & + & - & - & - & - & - & - & - & - & - \\
\hline
\end{tabular}

Key - T1=2.5 g/l aqueous extract; T2= 5 g/l aqueous extract; $T 3=50$ g/l methanolic extract; T4=75 g/l methanolic extract

Table 9: Haemagglutination Inhibition (Prophylactic Treatments)

\begin{tabular}{lllllllllllll}
\hline Treatment & $1 / 1$ & $1 / 2$ & $1 / 4$ & $1 / 8$ & $1 / 16$ & $1 / 32$ & $1 / 64$ & $1 / 128$ & $1 / 256$ & $1 / 512$ & $1 / 1024$ & $1 / 2048$ \\
\hline T6 & + & + & + & + & - & - & - & - & - & - & - & - \\
$\mathrm{T} 5$ & + & + & + & + & + & + & - & - & - & - & - & - \\
$\mathrm{T} 7$ & + & + & + & + & + & + & + & - & - & - & - & - \\
$\mathrm{T} 8$ & + & + & + & + & + & + & + & + & + & - & - & - \\
Control & + & + & - & - & - & - & - & - & - & - & - & -
\end{tabular}

Key $-\mathrm{T5}=2.5 \mathrm{~g} / \mathrm{l}$ aqueous extract; $\mathrm{T} 6=5 \mathrm{~g} / \mathrm{l}$ aqueous extract; $\mathrm{T} 7=50 \mathrm{~g} / \mathrm{l}$ methanolic extract; $\mathrm{T} 8=75 \mathrm{~g} / \mathrm{l}$ methanolic extract

\section{DISCUSSION}

Newcastle disease has been reported to be one of the major diseases bothering poultry with its high cost of management driving up the cost of pullet production $[16,17]$. The alleviated clinical signs seen could be as a result of the alkaloids present in Cucumis metuliferus which several authors have proven to be beneficial for various ailments. Alkaloids have been documented to have antiviral and antileukemic activities [18]. Our findings of fewer clinical signs in $75 \mathrm{~g} / 1$ curative and prophylactic treated groups agree with the findings of Wannang et al. [19] who showed that the isolated alkaloids from C. metuliferus at a dose of $600 \mathrm{mg} / \mathrm{kg}$ of the extract reduced the clinical signs seen in Newcastle disease and reversed the haemorrhagic lesions associated with the disease.
The mortality rates observed were not surprising since the clinical signs reflected similar findings and it is anticipated that higher mortality would occur in groups with more serious clinical signs and vice versa. Wakamatsu [20] worked on a similar isolate of NDV as Kudu 113 strain used in this study and reported $100 \%$ mortality post-infection. The result of this study showed that groups administered methanolic extract at $75 \mathrm{~g} / 1$ recorded fewer clinical signs and this would be translated into less mortality. Wannang [19] recorded a similar finding where extract (600 $\mathrm{mg} / \mathrm{kg}$ ) reversed the haemorrhagic lesions induced by Newcastle disease virus thus reducing clinical signs and mortality. These results suggest that Cucumis metuliferus may be effective for use in the management of 
Newcastle disease infection in chickens.

Findings from the post mortem lesions followed a similar pattern with groups $\mathrm{T} 4$ and T8, both administered $75 \mathrm{~g} / 1$ of methanolic extract of Cucumis metuliferus, showing the least post mortem lesions for the prophylactic and curative groups respectively. The control group exhibited all signs seen followed by groups $\mathrm{T} 1$ and $\mathrm{T} 5$ treated with $2.5 \mathrm{~g} / 1$ of aqueous extract of Cucumis metuliferus recorded the most post mortem lesions for the prophylactic and curative groups respectively.

The severity of the post mortem lesions seen may be attributed to the route of challenge (Ocular) which may enhance the clinical signs and gross lesions observed in most cases as the Newcastle disease virus replicates in the Haderian gland before spreading to other sites [21]. However less severe clinical signs and mortality seen in groups T4 and T8 also translated in the less severe post mortem lesions observed in these groups. There were fewer hemorrhagic lesions observed for these groups and this was probably due to the preventive effect of alkaloids in Cucumis metuliferus. Wannang [19] carried out a study that showed that the extract of Cucumis metuliferus at 600 $\mathrm{mg} / \mathrm{kg}$ reversed the haemorrhagic lesions induced by the Newcastle disease virus.

The result highlighted that the plant $C$. metuliferus increases the level of chicken PCV. The higher white blood cell count seen from blood pictures for groups T4 and T8 indicated higher white blood cell activity and thus higher chances of the immune system fighting off the infection when compared with other groups. This could translate to the lower clinical signs and mortality rates observed in these groups.
Usman [22] carried out a study which elucidated that the fruit of $C$. metuliferus was shown to increase the values of blood parameters: packed cell volume, haemoglobin, red blood cell and white blood cell counts. This is in agreement with the work of Wannang et al. [23], that the aqueous extract of C. metuliferus significantly increased the level of PCV in rats when given at $1000 \mathrm{mg} / \mathrm{kg}$. An increase in the PCV value of rabbits treated with C. metuliferus against trypanosomiasis was also reported [24]. Jimam et al [25] carried out a study using methanolic extract of $C$. metuliferus and observed that birds treated with 200, 400 and $600 \mathrm{mg} / \mathrm{kg}$ of the extract exhibited a significant $(\mathrm{P}<0.05)$ increase in $\mathrm{PCV}, \mathrm{Hb}$ and $\mathrm{RBC}$ count on day 14 and 21 after treatment. Similarly, a significant $(p<0.05)$ increase in RBC count was observed in birds treated with the extract at 400 and $600 \mathrm{mg} / \mathrm{kg}$ after 7 days post treatment 25 . Usman et al. [26] in their study also showed that C. metuliferus may be used as haematinic as well as in the treatment of malnutrition. The presence of iron in the fruit may have stimulated the production of RBC and this, therefore, confirmed the folkloric use of C. metuliferus as a haematinic agent [26].

Antibody titres for haemagglutination inhibition tests were indicated by the highest titre levels at which agglutination became absent thus indicating no antigen-antibody reaction at that titre. All groups showed an initial positive response. This could be attributed to maternally derived antibodies [27]. Similar results of maternal antibodies conferring protection in all groups have been reported by Agang et al., [28]. The results for HI were not surprising as the groups with the 
highest antibody titres had the lowest recorded clinical signs in curative and prophylactic groups respectively as well as mortality and postmortem lesions. The findings from the present study are in agreement with the observations by Anyawu et al. [29] that the fruit alkaloids of Cucumis metuliferus induced some levels of protective immunity against the lethal effects of Newcastle disease virus-LaSota using embryonated chicken eggs.

\section{Conclusion and Recommendation}

The study revealed that methanolic extract of Cucumis metuliferus at $75 \mathrm{mg} / \mathrm{l}$ showed good prophylactic and therapeutic promise and as such can be recommended for the control of NCD to farmers and that further studies be conducted to isolate the alkaloids of $C$. metuliferus responsible for these findings.

\section{Acknowledgements}

The authors would like to acknowledge TetFund and the Department of Animal Science, Federal University Dutsin-ma for their contribution towards the success of this research work.

\section{REFERENCES}

1. Salami, J.O., Egbulett, B.N., Kwaga, J.K.P., Yusufu, H.I. and Abdu, P.A. (1989). Disease diagnosed in poultry in Kaduna State, Nigeria. Bulletin of Animal Health and Production in Africa, 18: 123 - 125.

2. Alexander, D.J. (2003). Newcastle disease and other avian paramyxovirida infections. In: Diseases of Poultry, Saif, Y.M., Barnes, H. J., Glisson, Jr., Fadly AM., McDougal, L .R. and Swayne, D.E., 11th Ed, (Jordan, F. T. W.M., Patttison, M. Eds.). pp. 64 - 87.
3. Lawrence, D.R. and Bennett, P.N. (1995). Clinical Pharmacology ELBS with Churchill Livingston, Edinburgh, p. 686.

4. Evans W.C. (2009). Trease and Evans Pharmacognosy. Elsevier Health Sciences. pp. 125

5. Sinclair, S. (1998). Chinese herbs: a clinical review of Astragalus, Ligusticum, and Schizandrae. Altern.Med. Rev, 3:338-344.

6. Alawa, C.B.I., Adamu, A.M., Gefu, J.O., Ajanusi, O.J., Abdu, P.A., Jagun, A.G., Lamidi, O.S. and Oni, O.O. (2008). Ethnoveterinary practices in Nigeria: Survey of plants used as anthelmintics. Vom J. Vet. Sci, 5 (1): 2 11.

7. Sofowora, A., Ogunbodede, E. and Onayade A. (2013). The Role and Place of Medicinal Plants in the Strategies for Disease Prevention. Afr J Tradit Complement Altern Med, 10 (5): 210 229 http://dx.doi.org/10.4314/ajtcam.v10i5.2

8. Nandagopalan, V., Anand, S.P., Prabha, L., Selvakumar, U. and A., Doss. (2011). An ethnobotanical study in the Pudukkottai District. South India. Asian Journal of Experimental Biological Sciences, 2: 412 - 421.

9. Aggarwal, B.B., Sundaram, C.; Malani, N. and Ichikawa, H. (2007). Curcumin, "the Indian Solid Gold" Adv. Exp. Med. Biol, 595: 1 - 75.

10. Gupta, M.P, Solís, P.N., Calderón, A.I., Guinneau-Sinclair, F., Correa, M., Galdames, C., Guerra, C., Espinosa, A., Alvenda, G.I., Robles, G. and Ocampo, R. (2005). Medical ethnobotany of the Teribes of Bocas del Toro, Panama.J.Ethnopharmacol, 96: 389 401. 
11. Wannang, N. N. (2011) Aqueous Fruit Extract of Cucumis metuliferus E Mey. Ex Naud (Cucurbitaceae) Alters Behavioural Activities In Chicks. Production Agriculture and Technology, 7: (1): 84-89

12. Burkill, H.M. (1985). Useful Plants of West Tropical Africa.Vol.1, 2nd ed. Royal Botanic Gardens, London. pp. $570-605$

13. Enslin, P.R., Joubert, T.G. and Rehm, S. (1954). Bitter principles of the Cucurbitace a e I - P a p e r chromatography of bitter principle research. J. S. Afr. Chem. Inst, 7: 131 138.

14. Hamill, F.A., Apio, S., Mubiru, N.K., Bukenya-Ziraba, Mosango, M., Maganyi, O.W., and Soejarto D.D. (2002) Traditional herbal drugs of Southern Uganda, II: literature analysis and antimicrobial assays. Journal of Ethnopharmacology, 84(2003): 57/78

15. Isah, M. (2009). Combating water scarcity in Katsina. Retrieved 20 may, $\begin{array}{lllll}2 & 0 & 1 & 0\end{array}$ f $r$ o m http,//www.wikipedia.org/wiki/Dutsin ma.

16. Ibrahim,U. I. and Tanya, S. N. (2001) : Prevalence of antibodies infectious bursal disease (illD) in village chickens in Sahel Zone of Nigeria. Bulletin of Animal Health production Africa, 49: 150-152.

17. Bukar-Kolo Y.M., Ibrahim U.I. and Abubakar B. U. (2006) A survey of major constraints limiting commercial poultry production in and around Gombe metropolis. Nigerian Veterinary Journal, 27 (2): 75-78

18. Moore, P.S. and Pizza, C. (1992). Observations on the inhibition of HIV-1 reverse transcriptase by catechins. Biochem. J, 288: 717-719.
19. Wannang, Noel \& Jimam, Nanloh \& Simeon, Omale \& Dapar, Maxwell \& Gyang, Steven \& Aguiyi, John. (2010). Effects of Cucumis metuliferus (Cucurbitaceae) fruits on enzymes and haematological parameters in albino rats. African Journal of Biotechnology, 6(22):p 6.

20. Wakamatsu, N., king, D.J., Seal, B.S., Samal, S.K and Brown, C.C. (2006). The Pathogenesis of Newcastle disease. A comparison of selected Newcastle disease virus wild-type strains and their infectious clones. Virology, 353: 333 - 343 .

21. Agang, I. (2014). Evaluating the effect of momordicabalsamina Linn, Selenium and Lamivudine for the treatment of Newcastle Disease in pullets. An M.Sc. dissertation submitted to the School of Postgraduate Studies, Ahmadu Bello University, Zaria In Partial Fulfilment of the Requirement for the Degree of Master of Science in Veterinary Medicine.

22. Usman, J.G. (2014). Phytochemical Screening and Antibacterial Effects of Cucumis Metuliferus (Jelly Melon) E. Mey. Ex Naudin (Cucurbitaceae) Fruits against Fowl Typhoid. A Dissertation Submitted to the School of Postgraduate Studies, University of Maiduguri, In Partial Fulfilment of the Requirement for the Degree of Master of Science in Pharmacology.

23. Wannang, N., Jimam, N., Simeon, O., Dapar, M., Gyang, S. and Aguiyi, J. (2007) Effects of Cucumis metuliferus (Cucurbitaceae) fruits on enzymes and haematological parameters in albino rats. African Journal of Biotechnology, 6(22): 2515-2518

24. Abubakar A., Iliyasu B., Ojiegbu F.N., Igweh A.C., Shamaki B.U., Dung E.C. (2011) Evaluation of the 
antitrypanosomal activity of Cucumis metuliferus pulp extract in rabbits. $J$ MedPlant Res, 5(11):2136-2142.

25. Jimam, N. S., Wannang, N. N., Omale, S., Wetkos, D. D. and David S. (2012) Effect of C. metuliferus on some Metabolic Parameters in wistar strain albino rats. Scholarly Journal of Medicine, 2(4): 57-59

26. Usman J.G., Sodipo, O.A., Kwaghe, A.V., Wampana B., Umaru N.J.H. and Sandabe U.K. (2018) Effects of crude methanol extract of the fruit of Cucumis metuliferus (Cucurbitaceae) on some haematological parameters in Cockerels. The Journal of Phytopharmacology, 7(2): 106-110

27. Salisu U. S., Garba M. G., Sabo M. N., Jamilu R. Y., Zaharadeen A. S., Sanusi A. Z., Babashani M, Lawal M. (2019) Effect OfAqueos Extract of Momordica Balsamina and Cucumis Metuliferus Fruits on Newcastle Disease in Pullets. FUDMA Journal of Sciences, 4(2): 730 $-736$

28. Agang D., Abdu P.A., Saidu L. and Suleiman M.M. (2019). Evaluating the effect of Momordica balsamina linn, selenium and lamivudine for the treatment Newcastle disease in pullets. International Journal of Agricultural Research and Food Technology, 4(3): 255-264

29. Anyanwu, AnneA \& Jimam, Nanloh \& Wannang, NoelN. (2016). Assessment of the effects of Cucumis metuliferus fruits alkaloids against Newcastle disease virus-LaSota. Environmental Disease, 1: 130. 